\title{
InITIAL INVESTMENT TO 3D PRINTING TeCHNOLOgIES IN A CONSTRUCTION COMPANY
}

\author{
Zdenek Cernohorsky ${ }^{1}$, Petr Matejka ${ }^{2}$ \\ ${ }^{1}$ CTU in Prague, Faculty of Civil Engineering, Department of Construction Technology, Thakurova 7, \\ Prague, 166 29, Czech Republic, zdenek.cernohorsky@fsv.cvut.cz \\ ${ }^{2} \mathrm{CTU}$ in Prague, Faculty of Civil Engineering, Department of Construction Management and \\ Economics, Thakurova 7, Prague, 166 29, Czech Republic, petr.matejka@fsv.cvut.cz
}

\begin{abstract}
This article deals with an initial investment to 3D printing technologies in a construction company. The investment refers to the use of building information models and their integration with 3D printing technology within a construction company. In the first part, there will be discussed an introduction of 3D printing scheme in a construction company from a lifecycle perspective in general. As a part of this scheme, the ideal variant of an initial investment will be considered a.k.a a pilot project. In the second part, there will be a more detailed discussion of the pilot project, more about each activities which should be its parts and which should analyze cost categories. These categories will be about particular lifecycle stages of the pilot project. In the third part, a summary is done. This article could be a handout for a construction company in a term of an initial investment to 3D printing.
\end{abstract}

\section{Keywords}

3D printing; BIM; pilot project, lifecycle

\section{JEL Classification}

O32 management of technological Innovation and R\&D

DOI: https://doi.org/10.14311/bit.2017.01.03

Editorial information: journal Business \& IT, ISSN 2570-7434, CreativeCommons license (c) (1) published by CTU in Prague, 2017, http://bit.fsv.cvut.cz/ 


\section{Introduction}

Nowadays in the Czech Republic, construction companies are beginning make out what advantages BIM represents. Some companies use it more and some less. But the important thing is that BIM is, slowly but surely, starting to get into a professional public consciousness. 3D printing is not a very known term in the Czech building engineering. However, worldwide, this technology proves that it could be quite potential in the future.

During last twenty years, 3D printing technology has transformed into a high-end technology and it is not only used in industrial production and healthcare but also in consumer goods production and in the art. In the future, 3D printing technology will represent lots of advantages in comparison with conventional methods of production which may provide safer, faster and more effective construction process. Today abroad, many institutions have already dealt with linking 3D printing and a building engineering and there are really interesting international projects. Powder-based 3D printers are being used for rocks modeling [1], also ceramics [2], support parts [3, 4] and much more [5]. In this article, we will discuss the initial investment to 3D printing. Concretely, a pilot project should be used well in Czech construction companies.

\section{Methodology}

The main aim was to theoretically describe a suitable project to the initial investment to $3 \mathrm{D}$ printing in a Czech building company. The first necessary condition to make up this project was to gather up information about BIM and 3D printing. At first, this information was related to particular $3 \mathrm{D}$ printing technologies and chance to bring it together with BIM. Information was collected during the creation of the thesis "Cost Evaluation of 3D Printing Technology Using BIM in a Construction Company". Subsequently, a thinking method scheme of 3D printing introduction from a lifecycle perspective was created. In this case, a project management methodology was used. It discusses about lifecycles of each project. And the pilot project was built up by the connection of this scheme. Costs of each project phase were categorized and there was also shown an example of a sequence of individual processes. Above all, basis for the pilot project creation were my own practical experiences with 3D printing gained at Skanska a.s.

\section{Results}

\section{D Printing Implementation Scheme in a Building Company}

For easier implementation process of 3D printing technology, it is preferable if a company which is considering to introduce this technology already has actively used BIM methodology in their projects. In the case of a building company, it is not wise to buy expensive machines and software at the beginning. The ideal variant is to purchase a machine and only one worker will learn to work with and will find the ideal application of 3D printing in a pilot project. We would recommend the using of complicated technologies to the phases which may follow a successful pilot project.

The goal of the scheme is to intend a possible lifecycle implementation of 3D printing into a construction company. The scheme could be tended as a pattern for a company management who is thinking about introducing 3D printing.

The first point of this scheme expresses the idea of the possibility of introducing 3D printing in a construction company and relay it to a company management. In the case, when the company management will deal with the introduction of 3D printing technology, it would be appropriate to analyze possibilities and the ability of effective using this technology during the second point of the process. At this point, the management should analyze the range of an investment. It means to have 
a possibility to release a financial investment to each phase and determine the approximate period of these phases. Investment phases can be thought, initially to develop a pilot project and then a final project or to invest into further research. After analyzing the possibilities, the company management should define investments targets to 3D printing. Among these goals can be included, for example a successful pilot project, location specific fields of application, benefit definitions, possibility of using $3 \mathrm{D}$ printing in a final project, etc. After, the investment to the pilot project should be approved. Then, the pilot project should be realized and it should be evaluated. The management should issue an opinion which will determine further investment to 3D printing.

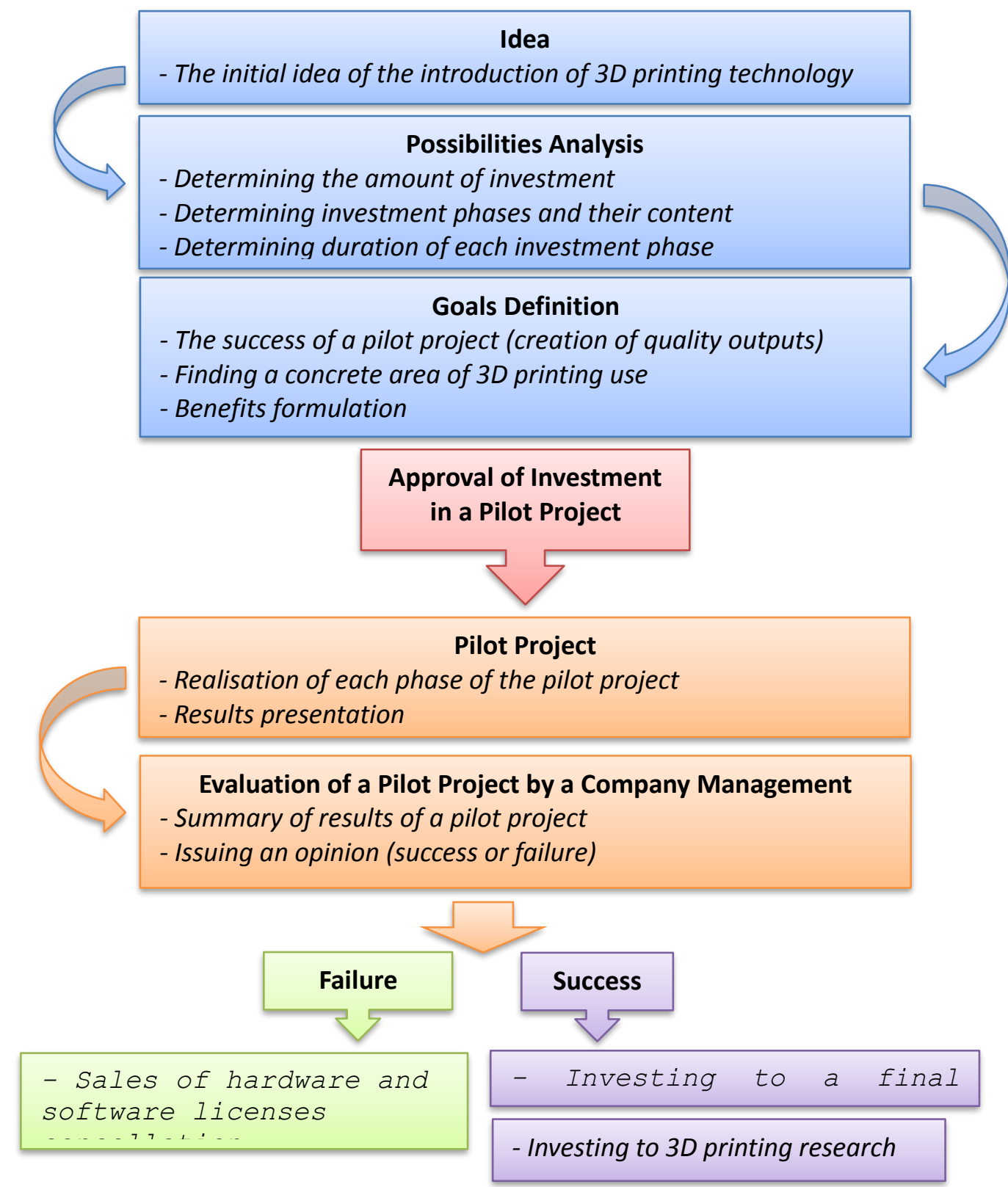

Figure 1: Example of the Pilot Project Lifecycle Introducing 3D Printing (source: authors)

\section{Pilot Project}

Because of the initial investment to 3D printing in the company is needed to analyze the various categories of costs and divide them into groups, it is ideal to structure these costs by the 
lifecycle. The pilot project does not generate profit. Therefore, it should be perceived as a research project. In this case, it is necessary to comprehend the lifecycle project calculation in general as a methodology to establish project costs in terms. The pilot project lifecycle should be divided into particular phases as any other investment project. Then, the pilot project should consist of tasks that have been approved by the company management during a preparatory (pre-investment) phase.

\section{Costs Categorization According to Various Lifecycle Stages of a Pilot Project}

Table 1: Cost Categorization According to Various Stages of a Pilot Project (source: authors)

\begin{tabular}{|c|c|}
\hline \multicolumn{2}{|c|}{ Cost Categorization of a Pilot Project } \\
\hline \multicolumn{2}{|c|}{ 1. Pre-investment (Concept and Planning) Phase } \\
\hline \multicolumn{2}{|c|}{ Design a subject of a pilot project } \\
\hline \multicolumn{2}{|c|}{ Making a feasibility study } \\
\hline \multicolumn{2}{|c|}{ Appropriate technology selection and investment possibilities } \\
\hline \multicolumn{2}{|c|}{ Approval processes } \\
\hline \multicolumn{2}{|c|}{ 2. Investment Phase } \\
\hline \multicolumn{2}{|c|}{ Investments to hardware and software } \\
\hline Hardware (HW) & Software (SW) \\
\hline 3D printer & CAD / BIM software \\
\hline Notebook & Animation software \\
\hline \multicolumn{2}{|c|}{ Transport } \\
\hline \multicolumn{2}{|c|}{ HW / SW Assembling and installation } \\
\hline \multicolumn{2}{|c|}{ 3. Operating (Implementation) Phase } \\
\hline \multicolumn{2}{|c|}{ Operating costs } \\
\hline \multicolumn{2}{|c|}{ Payments } \\
\hline \multicolumn{2}{|c|}{ Offices + energy } \\
\hline \multicolumn{2}{|c|}{ Printing material } \\
\hline \multicolumn{2}{|c|}{ Training courses } \\
\hline \multicolumn{2}{|c|}{ Service and maintenance } \\
\hline \multicolumn{2}{|c|}{ 4. End Lifecycle Phase of a Pilot Project } \\
\hline Liquidating & Start follow-up project \\
\hline $\begin{array}{c}\text { Termination of SW license } \\
\text { agreements }\end{array}$ & \multirow{3}{*}{$\begin{array}{l}\text { Pre-investment phase of final / } \\
\text { of follow-up research project }\end{array}$} \\
\hline HW Sale / Liquidation & \\
\hline Material liquidation & \\
\hline
\end{tabular}

Because of a lifecycle perspective is necessary to divide the pilot project into various phases. Consequently, in these phases comes to processes from which the pilot project costs can be determined.

In the pre-investment phase, there should be a clear aim definition, costs categorization and processes analyzing which will be conducted as a part of the pilot project. These processes should be attended by the management in cooperation with BIM and IT teams. 
During the investment phase, a hardware and a software should be bought and installed. That is why the pilot project will begin. There should be close cooperation between BIM staffs, IT team and companies that deliver a software and a hardware.

During the pilot project phase, there should be outgo working costs. The working costs include payroll costs, printing material costs, rent, maintenance costs, service and training.

The end phase closes the pilot project lifecycle. In the case of the pilot project has this phase two possible solutions. If the pilot project is successful and the company wants to continue in the development and in 3D printing application, a new project will be launched. This project can be a related research project or a final project in which printed models will be practically used. Even as the research project and the final project could coexist independently. In the case of failure, the pilot project should be done a standpoint of immediate outlay to end use of 3D printing technologies (get rid of residual materials, sale or liquidation a hardware and stoppage licensing agreements of each software).

To decide about an investment into the project is necessary to think about whole lifecycle of the project because it consumes costs throughout its duration [6].

\section{Example of Processes Division in a Pilot Project}

The pilot project should be divided into several processes. These processes should be arranged of their duration because there is necessary to ensure licenses of needed software's. The pilot project of 3D printing introduction should take about one year because of research complexity and a favorable purchase of software licenses. During one year period, most of companies, that sell a software, have better prices than in the case of ordering a software only for several months. And because there is enough time to all processes in the project. This is only a recommended duration. This time, according to the needs and set goals, can be various in each company.

The shown example of the pilot project is concerning the use of one printing technology. In this project, two good outcomes should be made and found areas of potential use of printed models in a company. In the case of using more printing technologies, this procedure can be applied for each technology separately. In the first phase of the pilot project, a software should be installed, a printing run, doing a test of good working and trial printout. A part of the first phase should also be materials studies which is connected with a software and another equipment. In the next phase, the first outputs of BIM model should be made. These outcomes may be an exterior or an interior printing model. Important is to use specific building information model to the outputs.

In the next phase, it would be appropriate to use this model during a project presentation to an investor. In the case of print model of an interior apartment is good to present a flat layout to a prospective client by this way. If the pilot project took place within the already ended project, results would be present to the company management. Because of the presentation, by an investor, a client or a leadership reaction can be estimated the potential benefits. Another phase should be directed to print a specific detail of BIM model. For example, this detail can be a place where is a collision or a cut of ceiling with HVAC components. Subsequently, copies would be appropriate consulted with building techniques and find with them concrete possibilities of practical use. In the last stage, the results should be to evaluated and the presentation of the project should be done to the management of the company. If the pilot project was successful, it would be possible to increase investment to 3D printing and the use of this technology in a final project or beginning research of possibilities of using new technologies. 
Table 2: Example of Operations Sequence of a Pilot Project Introducing 3D Printing

\begin{tabular}{|c|c|}
\hline \multicolumn{2}{|c|}{ Intoducing 3D Printing in a Construction Company } \\
\hline \multicolumn{2}{|c|}{ Pilot Project } \\
\hline Order & Processes \\
\hline 1 & Studies, equipment launching, functional tests \\
\hline 2 & Initial output from BIM model \\
\hline 3 & Output presentation for investors / clients \\
\hline 4 & Evaluation of the first project part \\
\hline 5 & Print concrete details from BIM model \\
\hline 6 & Possibilities of using printed details \\
\hline 7 & Evaluation and presentation project results \\
\hline
\end{tabular}

\section{Conclusion}

It is necessary to understand the pilot project as an interdepartmental research project that aims to find suitable areas of 3D printing using in a particular building company. By the using this research and its development, a construction company can create its own know-how to increase their competitiveness and use the printed models in own projects. The company will also partially prepare for future application of 3D printing in a construction industry.

The introduction of 3D printing technology is particularly suitable for companies that implement or has already used BIM methodology in their projects and have the opportunity to work with high-quality computer technology. Also, important is a good IT support. Construction companies can actively use 3D printing within the land, transport, water and special engineering. This implementation may also relate to design offices and architectural studies.

\section{Acknowledgement details}

This work was supported by the Grant Agency of the Czech Technical University in Prague, grant SGS15/132/OHK1/2T/11: Vyhodnocování efektivity výstavbových projektů při použití metodiky BIM

\section{References}

[1] Fereshtenejad, S., \& Song, J. -. (2016). Fundamental study on applicability of powder-based 3D printer for physical modeling in rock mechanics. Rock Mechanics and Rock Engineering, 49(6), 2065-2074. doi:10.1007/s00603-015-0904-x

[2] Huson, D. (2010). The digital fabrication of ceramics by 3D powder printing. Paper presented at the International Conference on Digital Printing Technologies, 545-548.

[3] Rosales, S., Ferrándiz, S., Reig, M. J., \& Seguí, J. (2017). Study of soluble supports generation in 3d printed part. Procedia Manufacturing, 13, 833-839. doi:10.1016/j.promfg.2017.09.188

[4] Lischke, F., \& Tovar, A. (2016). Design of self-supported 3D printed parts for fused deposition modeling. Paper presented at the Proceedings of the ASME Design Engineering Technical Conference, , 4 doi:10.1115/DETC2016-60569.pdf

[5] Singh, O. P., Ahmed, S. M., \& Abhilash, M. (2015). Modern 3D printing technologies: Future trends and developments. Recent Patents on Engineering, 9(2), 91-103.

https://doi.org/10.2174/1872212109666150213000747

[6] BUSINESSINFO.CZ. Náklady projektu a stanovení jeho ceny. Available online at: http://www.businessinfo.cz/cs/clanky/naklady-projektu-a-stanoveni-jeho-ceny2858.html\#!\&chapter=1 (accessed 29 Dec 2016) 